\title{
PALATALIZATION OF CONSONANTS IN STANDARD LITHUANIAN FROM THE VIEWPOINT OF ACOUSTIC PHONETICS
}

\author{
Jolita URBANAVIČIENË
}

\begin{abstract}
According to palatalization, Standard Lithuanian has a non-palatalized consonant, a palatalized consonant (to denote the secondary palatalization) and one palatal consonant $/ \mathrm{j} /$ (to denote the primary palatalization). The 'primary palatalization' means that the movement of the body of the tongue against the hard palate is the only way of articulating the consonant; the secondary palatalization means that the movement of the tongue is a variant of articulation for the consonant ([i]-like articulation). The article does not include a separate analysis of palatalization resulting from assimilation (before the front vowels) and palatalization as a manifestation of the phoneme $/ \mathrm{j} /$ (before the back vowels). It is assumed that it should be an object of diachronic rather than synchronic research.

Palatalized and non-palatalized consonants of Standard Lithuanian were analysed in prevocalic positions in isolated symmetric CVC sequences using experimental research methods. According to research, palatalization of Lithuanian obstruents is recognized by the following acoustic features: 1) frequency of the spectral peak: frequencies of the palatalized fricatives (particularly labiodental and palatovelar fricatives) and affricates are higher; 2) relative intensity: palatalized fricatives and affricates have higher relative intensity; 3 ) indices of locus equations: palatalized consonants have lower slopes and higher y-intercepts than their non-palatalized equivalents. The acoustic features of Lithuanian consonants are compared with the corresponding features of Latvian consonants.
\end{abstract}

Keywords: Standard Lithuanian, acoustic phonetics, obstruents, secondary palatalization.

Aim of the research. In Lithuanian linguistics, the concepts of soft and hard consonants are more widely used, although some linguists argue that they are 'impressionistic' or 'metaphoric' (Pakerys, 2003: 74). In the present work, the concept of the 'soft' consonant is not sufficient, because it does not allow differentiation between the primary palatalization (when the movement of the body of the tongue against the hard palate is the only way of articulating the consonant) and the secondary palatalization (when this

\footnotetext{
* Senior researcher at the Research Center of the Standard Language, PhD, Institute of the Lithuanian Language, P.Vileišio str. 5, LT-10308 Vilnius, LITHUANIA (jolita.urb@gmail.com).
} 
movement of the tongue is a variant of articulation for the consonant) (see Ambrazevičius, 2012 and the original references). Therefore, in this work the internationally accepted terms will be used: palatal consonant (to denote the primary palatalization) and palatalized consonant (to denote the secondary palatalization).

The main aim of this article is to discuss distinctive acoustic features of palatalized and non-palatalized consonants of Standard Lithuanian using experimental research methods.

Review of the background literature. The most important work of the Lithuanian philological school the monograph Theoretical Foundations of Lithuanian Phonology by AleksasGirdenis (2014) presents four possible interpretations of palatalization of consonants of the Lithuanian language. AleksasGirdenis proved that it is most reasonable to treat soft and hard consonants as independent phonemes and fronted back vowels as allophones of back voiced phonemes (Girdenis, 2014: 257-262). The author sticks to this interpretation in the present article too. Girdenis concluded the discussion about the interpretation of affricates and clusters $[t-s],[t-\breve{s}],[d-$ $\mathrm{z}],[\mathrm{d}-\mathrm{z}]$ that had been taking place in Lithuanian linguistics for a long time: on the basis of a shorter duration of pronouncing the affricates, their smooth transition from occlusion (plosive consonants) to narrowness (fricative consonants) and regular rules of the structure of STR-type clusters he proposed to interpret the affricates as independent phonemes rather than as combination of phonemes (Girdenis, 2014: 87-88; LG, 2006: 39). The statistical investigations of the phonemes of the Standard Lithuanian Language carried out by AleksasGirdenis and Vida Karosienè (Karosienè, Girdenis, 1993: 28-38; Girdenis, Karosiene, 2010) deserve mention. For example, they established that the most frequently used consonants in the Lithuanian language are as follows: /s, j, k, t, o/, whereas the consonants /z, $z^{j}, f, f^{j}, t s, t f, d z^{j}, \gamma^{j}, x, x^{j} /$ are the least frequently encountered ones. Moreover, high values of the coefficient of variation are characteristic of peripheral phonemes (Karosiene, Girdenis, 1993: 35-36). Some preliminary hypothesis proposed by Girdenis, e.g. about non-palatalization of the palatal [k], [g] before the soft consonants (Girdenis, 2000: 165-167) still awaits further thorough substantiation.

In her articles Danutė Balšaitytė investigated the acoustic features of palatalization, affricatisation and velarisation of fricative consonants, and their effect on the F2 formant of the neighbouring vowels (Балшайтите, 2005: 87-96; 2006: 65-73; 2007: 154-162). A regressive effect of soft consonants on the spectrum of the short high and low vowels was analysed by Regina Kliukienè. She established that vowels were pronounced in a higher timbre (in a higher second formant) before the palatalized consonants, they were characterised by a higher position of the middle part of the tongue (Kliukienè, 2002: 73-78). In their investigations Asta 
Kazlauskienè, Arimantas Raškinis and Sigita Dereškevičiūtė sought to establish whether palatalization and the activity of the vocal cords had an impact on the duration of fricatives, plosives and frictionless continuants (Kazlauskienė, 2006: 148-154; Kazlauskienė, Raškinis, 2006: 64-69; Dereškevičiūte, 2008: 15-19). In her thesis Acoustic Features of Consonants of the Lithuanian Language (2013) Dereškevičiūte investigated the quantity and duration of the consonants of the Standard Lithuanian language on the basis of LPC spectrum analysis. Rytis Ambrazevicius was the first to apply the method of loci to investigate Lithuanian consonants: having studied the plosives and sonants he summarised that the distinguishing feature of the soft and hard consonants was F2locus (Ambrazevičius 2010: 5-10; 2012: 5-13). The latest experimental investigations of consonants are summarised in the book Acoustic Features of Southern and Eastern Highlanders (2014) by RytisAmbrazevičiaus and Asta Leskauskaite. The data of eastern and southern highlanders is compared with the data of the Standard Language in the book. The greatest attention was paid to palatalization and voicing of consonants.

Classification of Lithuanian consonant phonemes.Lithuanian consonant phonemes are represented by the International Phonetics Association (IPA, 2015) ${ }^{1}$ symbols in this article. The classification is based on the articulatory features of the consonants that are grouped according to four main criteria: 1) voicing; 2) manner of articulation; 3) place of articulation; 4) palatalization ${ }^{2}$.

The consonant system of Standard Lithuanian consists of 45 consonant phonemes (LG, 2006: 35). According to voicing, there are 27 voiced $\left./ b, b^{j}, d, d^{j}, z, z^{j}, d z, z^{j}, 3,3^{j}, d\right\}, d 3^{j}, g, g^{j}, \gamma, \gamma^{j} ; m, m^{j}, v, v^{j}, n, n^{j}, 1, l^{j}$, $\mathrm{r}, \mathrm{r}^{\mathrm{j}}, \mathrm{j} /$ and 18 voiceless $/ \mathrm{p}, \mathrm{p}^{\mathrm{j}}, \mathrm{f}, \mathrm{f}, \mathrm{t}, \mathrm{t}^{\mathrm{j}}, \mathrm{s}, \mathrm{s}^{\mathrm{j}}, \mathrm{ts}^{\mathrm{s}}, \mathrm{s}^{\mathrm{j}}, \int, \mathrm{f}^{\mathrm{j}}, \mathfrak{t}^{\mathrm{j}}, \mathrm{t}^{\mathrm{j}}, \mathrm{k}, \mathrm{k}^{\mathrm{j}}, \mathrm{x}, \mathrm{x}^{\mathrm{j}} /$ consonants. Articulation of voiced and voiceless consonants is very similar: according to the place of articulation, as well as the manner of articulation they are attributed to the same classes of consonants.

According to the manner of articulation Lithuanian consonants are divided into: 1) plosives $/ \mathrm{b}, \mathrm{b}^{\mathrm{j}}, \mathrm{p}, \mathrm{p}^{\mathrm{j}}, \mathrm{d}, \mathrm{d}^{\mathrm{j}}, \mathrm{t}, \mathrm{t}^{\mathrm{j}}, \mathrm{g}, \mathrm{g}^{\mathrm{j}}, \mathrm{k}, \mathrm{k}^{\mathrm{j}} / ;$ 2) fricatives $/ \mathrm{f}, \mathrm{f}$,

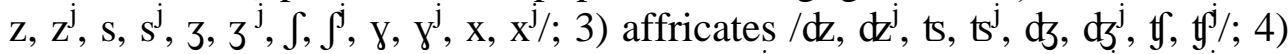
frictionless continuants (approximants) $/ \mathrm{v}, \mathrm{v}^{\mathrm{j}}, \mathrm{j} / ; 5$ ) nasals $/ \mathrm{m}, \mathrm{m}^{\mathrm{j}}, \mathrm{n}, \mathrm{n}^{\mathrm{j}} / ; 6$ ) laterals $/ 1, \mathrm{l}^{\mathrm{j}} /$; 7) trills $/ \mathrm{r}, \mathrm{r}^{\mathrm{j}} /$.

\footnotetext{
${ }^{1}$ The IPA symbols used in this article to denote the consonants of the contemporary Baltic languages were selected in the progress of the project 'Acoustic Characteristics of the Sounds of the Contemporary Baltic Languages (Experimental Study)' (financed by the Research Council of Lithuania,2013-2015, project manager Jurgita Jaroslaviene, PhD).

${ }^{2}$ Palatalized Lithuanian consonants, following the conventions of the IPA, are represented by adding to the symbol of a consonant a modifying symbol, a superscript symbol for palatal approximant $j$, for example $/ \mathrm{b}^{\mathrm{j} /}, / \mathrm{p}^{\mathrm{j} /}$.
} 
According to the place of articulation Lithuanian consonants are divided into: 1) bilabial $/ \mathrm{b}, \mathrm{b}^{\mathrm{j}}, \mathrm{p}, \mathrm{p}^{\mathrm{j}} ; \mathrm{m}, \mathrm{m}^{\mathrm{j}} / ;$ 2) labiodental $/ \mathrm{f}, \mathrm{fj} ; \mathrm{v}, \mathrm{v}^{\mathrm{j}} / ; 3$ ) dental $/ z, z^{\mathrm{j}}, \mathrm{s}, \mathrm{s}^{\mathrm{j}}, \mathrm{dz}, \mathrm{dz}^{\mathrm{j}}, \mathrm{ts}, \mathrm{ts}^{\mathrm{j}} ; \mathrm{n}, \mathrm{n}^{\mathrm{j}}, \mathrm{l} / ; 4$ ) alveolar $/ 3,3^{\mathrm{j}}, \int, \mathrm{f}^{\mathrm{j}}, \mathrm{d}, \mathrm{d}^{\mathrm{j}}, \mathfrak{t g}^{\mathrm{j}}, \mathrm{t}^{\mathrm{j}} ; \mathrm{l}^{\mathrm{j}}$, $\mathrm{r}, \mathrm{r}^{\mathrm{j}} /$; 5) palatal $/ \mathrm{j} /$; 6) palatovelar $/ \mathrm{g}^{\mathrm{j}}, \mathrm{k}^{\mathrm{j}}, \mathrm{\gamma}^{\mathrm{j}}, \mathrm{x}^{\mathrm{j}} /$; 7) velar $/ \mathrm{g}, \mathrm{k}, \mathrm{\gamma}, \mathrm{x} /$. These classes are differentiated by the passive organs of speech $^{3}$.

According to palatalization, Lithuanian has palatalized $\left(b^{j}, p^{j}, f^{j}, z^{j}\right.$, $\left.\mathrm{s}^{\mathrm{j}}, \mathrm{d}^{\mathrm{j}}, \mathrm{t}^{\mathrm{j}}, \mathrm{d}^{\mathrm{j}}, \mathrm{ts}^{\mathrm{j}}, \mathrm{z}^{\mathrm{j}}, \mathrm{f}^{\mathrm{j}}, \mathrm{d}^{\mathrm{j}}, \mathrm{t}^{\mathrm{j}}, \mathrm{g}^{\mathrm{j}}, \mathrm{k}^{\mathrm{j}}, \mathrm{\gamma}^{\mathrm{j}}, \mathrm{x}^{\mathrm{j}}, \mathrm{m}^{\mathrm{j}}, \mathrm{v}^{\mathrm{j}}, \mathrm{n}^{\mathrm{j}}, \mathrm{l}^{\mathrm{j}}, \mathrm{r}^{\mathrm{j}} /\right)$ and non-palatalized (/b, p, f, z, s, d, t, dz, ts, $\left.\left.3, \int, d\right\}, t 5, y, x, g, k ; m, v, n, 1, r /\right)$ consonants. Consonant $/ \mathrm{j} /$ is usually regarded as palatalized in the classifications of Lithuanian consonants on the basis of its phonological functions (Girdenis, 2014: 224; Pakerys, 2003: 75). According to its articulatory features it is uniformly regarded as the only Lithuanian palatal consonant, because raising the body of the tongue against the hard palate is the main manner of its articulation (Pakerys, 2003: 74). Thus, in this articulatory classification, a separate subcategory of palatal consonants is distinguished, albeit consisting of only one consonant phoneme $/ \mathrm{j} /$.

The summary of the articulatory classification of Lithuanian consonants is presented in Table 1.

Table 1.Articulatory classification of Lithuanian consonant phonemes (based on IPA)

\begin{tabular}{|c|c|c|c|c|c|c|c|}
\hline \multirow[b]{2}{*}{$\begin{array}{l}\text { Manner of } \\
\text { articulation }\end{array}$} & \multicolumn{7}{|c|}{ Place of articulation } \\
\hline & bilabial & labiodental & dental & alveolar & palatal & palatovelar & velar \\
\hline plosive & $\begin{array}{l}/ \mathrm{p} /-/ \mathrm{b} / \\
/ \mathrm{p}^{\mathrm{j}} /-/ \mathrm{b}^{\mathrm{j}} /\end{array}$ & & $\begin{array}{l}/ \mathrm{t} /-/ \mathrm{d} / \\
/ \mathrm{t}^{\mathrm{j}} /-/ \mathrm{d}^{\mathrm{j}} /\end{array}$ & & & $/ \mathrm{k}^{\mathrm{j}} /-/ \mathrm{g}^{\mathrm{j}} /$ & $/ \mathrm{k} /-/ \mathrm{g} /$ \\
\hline fricative & & $\begin{array}{l}/ \mathrm{f} / \\
/ \mathrm{f} /\end{array}$ & $\begin{array}{l}/ \mathrm{s} /-\mid \mathrm{z} / \\
/ \mathrm{s}^{\mathrm{j}} /-/ \mathrm{z}^{\mathrm{j}} /\end{array}$ & $\begin{array}{l}|S /-| 3^{j} \\
\mid \mathrm{j}^{\mathrm{j}} /-/ \mathrm{3}^{\mathrm{j}} /\end{array}$ & & $/ \mathrm{x}^{\mathrm{j}} /-/ \mathrm{y}^{\mathrm{j}} /$ & $/ \mathrm{x} /-/ \mathrm{y} /$ \\
\hline affricate & & & $\begin{array}{l}/ \mathrm{ts} /-/ \mathrm{d} / \\
/ \mathrm{ts}^{\mathrm{j}} /-/ \mathrm{d}^{\mathrm{j}} /\end{array}$ & $\begin{array}{l}/ \mathrm{t} /-/ \mathrm{d}_{3} / \\
/ \mathrm{t}^{\mathrm{j}} /-/ \mathrm{d}^{\mathrm{j}} /\end{array}$ & & & \\
\hline $\begin{array}{c}\text { frictionless } \\
\text { continuant } \\
\text { (approximant) }\end{array}$ & & $\begin{array}{l}/ v / \\
/ v^{j} /\end{array}$ & & & $/ \mathrm{j} /$ & & \\
\hline nasal & $\begin{array}{l}/ \mathrm{m}^{\mathrm{j}} / \\
/ \mathrm{m}^{\mathrm{j}} /\end{array}$ & & $\begin{array}{l}/ \mathrm{n} / \\
/ \mathrm{n}^{\mathrm{j}} /\end{array}$ & & & & \\
\hline lateral & & & $/ 1 /$ & $/ 1^{\mathrm{j} /}$ & & & \\
\hline trill & & & & $\begin{array}{l}/ \mathrm{r} / \\
/ \mathrm{r}^{\mathrm{j}} /\end{array}$ & & & \\
\hline
\end{tabular}

\footnotetext{
${ }^{3}$ In earlier classifications of Lithuanian sounds based on the active organs of speech, next to the labial consonants back front tongue, mid tongue and back tongue consonants were distinguished (see LKG, 1965: 71; Mikalauskaite, 1975: 38; Pakerys, 2003: 73).
} 
Voiceless consonant phonemes in the IPA classification traditionally are written on the left side of the Table cells, and voiced phonemes are written on the right; the manner of articulation is designated by rows; the place of articulation is designated by columns; palatalized consonant phonemes are written below non-palatalized phonemes (cf. Table 1).

Recorded material and research specifications.Consonants were analysed in prevocalic positions in isolated symmetric CVC sequences where $\mathrm{C}$ means a plosive, and $\mathrm{V}$ means a short or long vowel, e. g.:

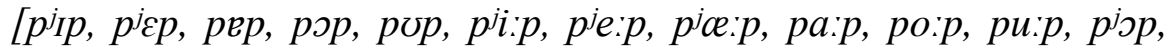
$\left.p^{j} 0: p, p^{j} \circlearrowleft p, p^{i} u: p\right]$.

This material was read by 12 Lithuanian informants, 6 male and 6 female, between the ages of 20 and 50. Each segment was repeated 3-5 times. The material for research was recorded with the help of the digital high resolution audio recorder Tascam DR-100MK II and the head-set microphone $A K G C 520$. The signal was sampled at a rate of $44100 \mathrm{~Hz}$ (16bit quantization). It was noticed that in pronouncing the plosives in isolated CVC type syllables the stress was not crucial: Lithuanian long syllables were pronounced with the circumflex (Lith. tvirtagale) accent (because circumflex is a non-marked variant in the final syllables of the words or one-syllable words).

The analysis of the sounds was performed using the free license sound processing and the analysis software program Praat (5.3.63 and its later versions developed by Paul Boersma and David Weenink (Boersma, Weenink, 2012). The obtained data were further processed using MS Excel and SPSS (version 19, IBM Corporation).

Research methods of consonants and a description of the results. Only the obstruents rather than a whole group of consonants are analysed: plosives, fricatives and affricates (this research does not include sonorants). The following features of obstruents were investigated: 1) duration of the release phase; 2) energy distribution in the spectrum on the basis of FFT spectral shapes; 3) frequencies of the spectral peaks; 4) relative intensity (intensity of the spectral peaks); 5) F2 transition according to the locus equations. Palatalization of obstruents is recognized by the last three acoustic features.

1. Spectral peak. The term 'spectral peak' characterises the place of the spectrum where the maximum concentration of spectral energy is fixed. The arrangement of spectral peaks in FFT (a fast Fourier transform) spectrum is determined by the resonators of the oral cavity therefore the study of the FFT spectra provides information about the place of articulation of the consonant, as well as about palatalization.

Having compared frequencies of the spectral peak of the nonpalatalized and palatalized consonants of the Lithuanian language it was noticed that palatalization heightens frequencies of the spectral peaks of the 
consonants. Dependence of the consonant spectrum on the place of articulation of a consonant has been recorded in the investigations of other languages too and is to be regarded as the universal of acoustics of the language (Johnson, 2003: 124-125; Kent, Read, 2002: 42).

To define the frequency value of the spectral peak (in Hz), FFT spectra for all Lithuanian consonants in the sample were obtained with PRAAT. The computer mouse pointer was moved to the centre of the noise segment of the plosive, Select was pressed and the option Movestart of selection by was chosen; the distance of $10 \mathrm{~ms}$ was selected, then the options Spectrum - View spectral slice - View - Zoom were chosen and the range from 0.0 to $8000.0 \mathrm{~Hz}$ was defined (Figures 1-2). To obtain an approximately equal number of spectral elements and thus to be able to compare the FFT spectra, the spectra of all plosives (disregarding the manner of articulation) were obtained from the same durational interval (10 $\mathrm{ms}$ ), which is identified in the oscillograms and the dynamic spectrograms of the plosives. The indicated duration was chosen on the premise that in most cases the segment from which the interval was taken was longer than $10 \mathrm{~ms}$ and therefore the start of the vowel that could affect the energy distribution in the FFT spectrum fell outside this interval.

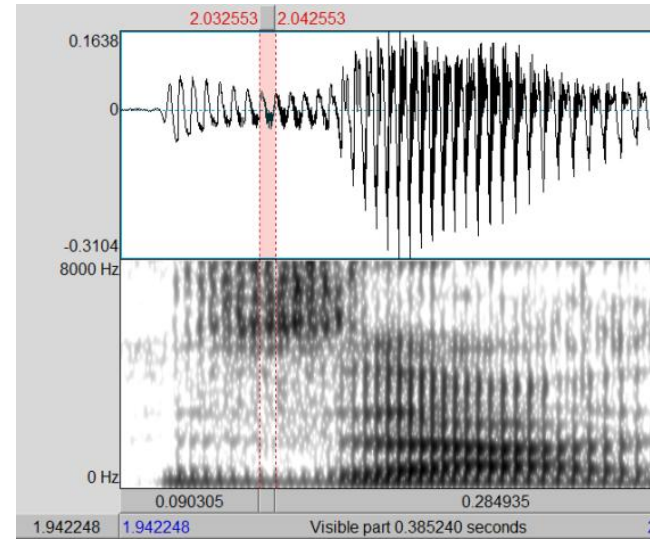

Figure 1. Intervals of $10 \mathrm{~ms}$ : voiced fricative $[\mathrm{z}]$

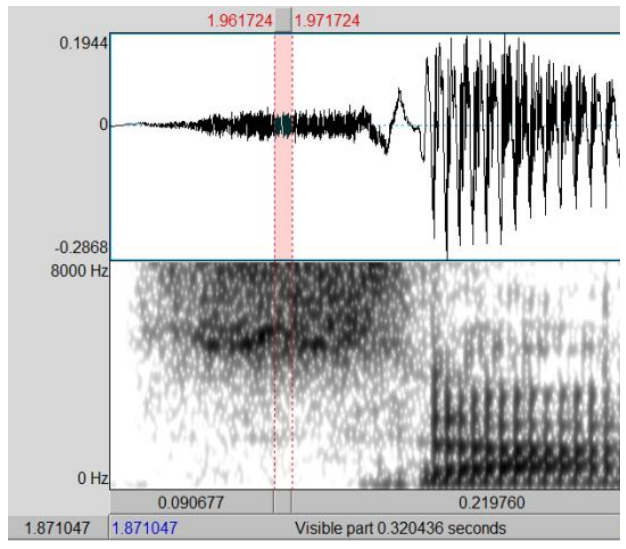

Figure 2. Intervals of $10 \mathrm{~ms}$ : voiceless fricative [s]

In bilabial or dental plosives, when the release phase is shorter than $10 \mathrm{~ms}$, spectrograms show a shorter segment corresponding to the release phase without reaching the start of the vowel.

Hence, in the obtained FFT spectra the energy distribution was analysed within the range of $0-8000 \mathrm{~Hz}$. The frequencies were measured in the spectrum of the dominating, i.e. in the highest peak (Figures 3-4). 


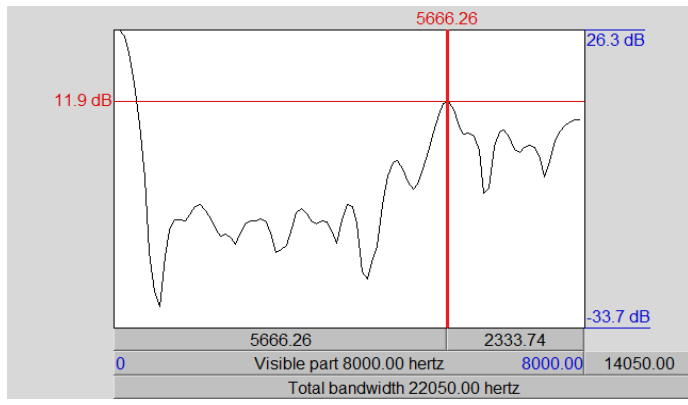

Figure 3. FFT spectrum of the voiced fricative [z]

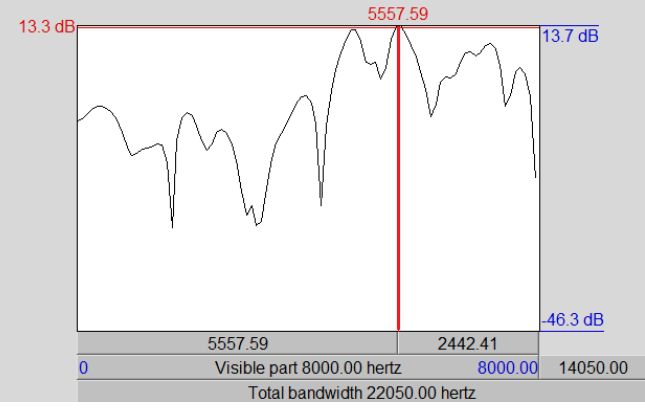

Figure 4. FFT spectrum of the voiceless fricative [s]

In this article the range of $0-8000 \mathrm{~Hz}$ is considered to be optimal because it allows the comparison of the results obtained with the results of other studies reviewed in literature to be made, and at the same time is broad enough not to lose any crucial acoustic information. Acoustic information over $10000 \mathrm{~Hz}$ does not play the key role in communication as the human ability to perceive and analyse sounds in such frequencies is rather limited (Johnson, 2003: 27).

The calculated statistical means of the frequency of the spectral peak for Lithuanian obstruents increases in the following sequence (Figures 5-6):

velar $[\mathrm{x}],[\mathrm{\gamma}]<$ palatalized labial $\left[\mathrm{b}^{\mathrm{j}}\right],\left[\mathrm{p}^{\mathrm{j}}\right]<$ labiodental $[\mathrm{f}]<$ dental [d], [t] < labial[p], [b] < alveolar [ $]$ ], [3] < palatovelar $\left[\mathrm{k}^{\mathrm{j}}\right],\left[\mathrm{g}^{\mathrm{j}}\right],\left[\mathrm{\gamma}^{\mathrm{j}}\right],\left[\mathrm{x}^{\mathrm{j}}\right]<$ velar $[\mathrm{g}],[\mathrm{k}]<$ palatalized labiodental $\left[\mathrm{f}^{\mathrm{j}}\right]<$ alveolar $[\mathrm{d}],[\mathrm{g}]<$ palatalized alveolar $\left[\mathrm{j}^{\mathrm{j}}\right],\left[\mathrm{t}^{\mathrm{j}}\right],\left[\mathrm{3}^{\mathrm{j}}\right],\left[\mathrm{d}^{\mathrm{j}}\right]<$ palatalized dental $\left[\mathrm{d}^{\mathrm{j}}\right]\left[\mathrm{t}^{\mathrm{j}}\right]<\operatorname{dental}[\mathrm{ts}],[\mathrm{z}]$, [c], $[\mathrm{s}]<$ palatalized dental $\left[\mathrm{z}^{\mathrm{j}}\right],\left[\mathrm{s}^{\mathrm{j}}\right],\left[\mathrm{t}^{\mathrm{j}}\right],\left[\mathrm{c}^{\mathrm{j}}\right]$.

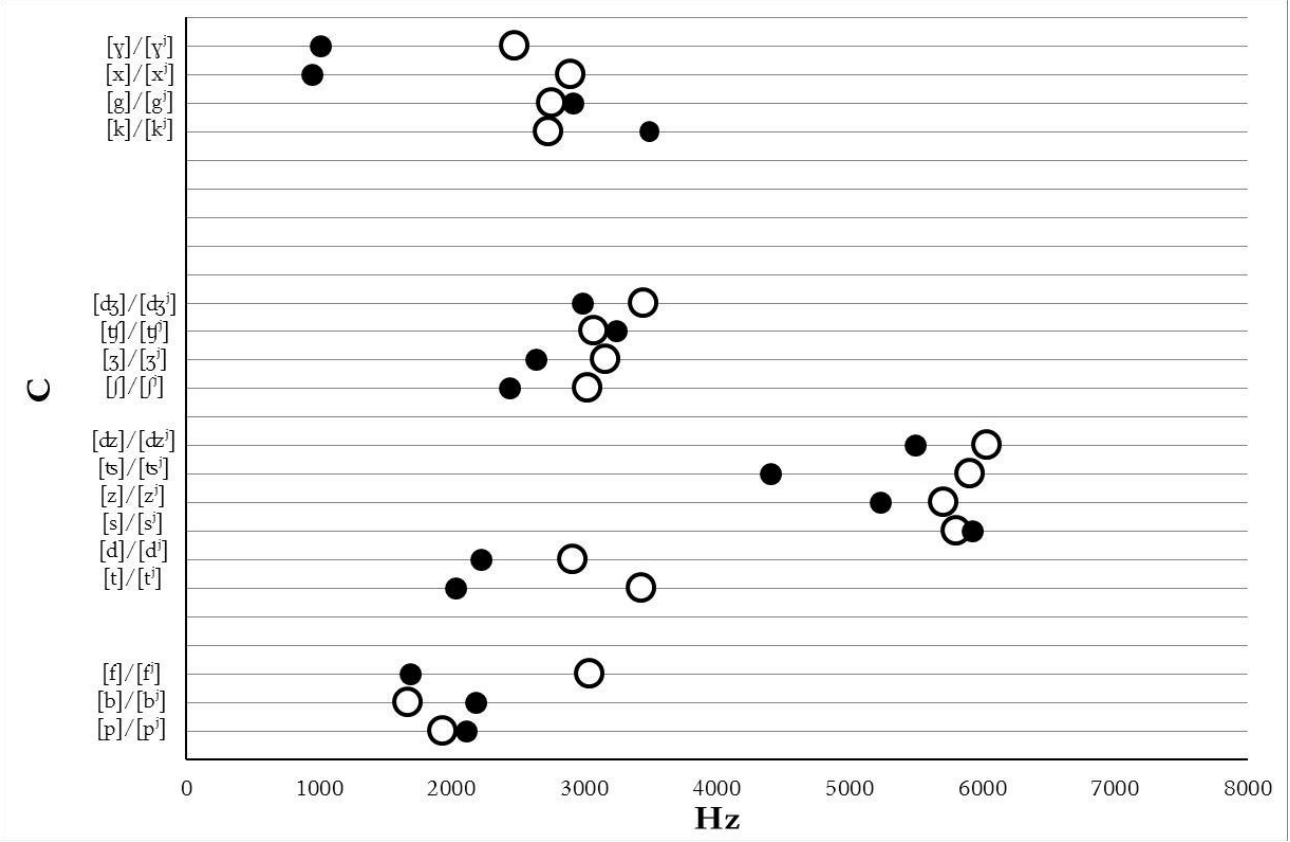

Figure 5. Frequencies of the spectral peaks: male data (Onon-palatalized obstruent, Opalatalized obstruent) 


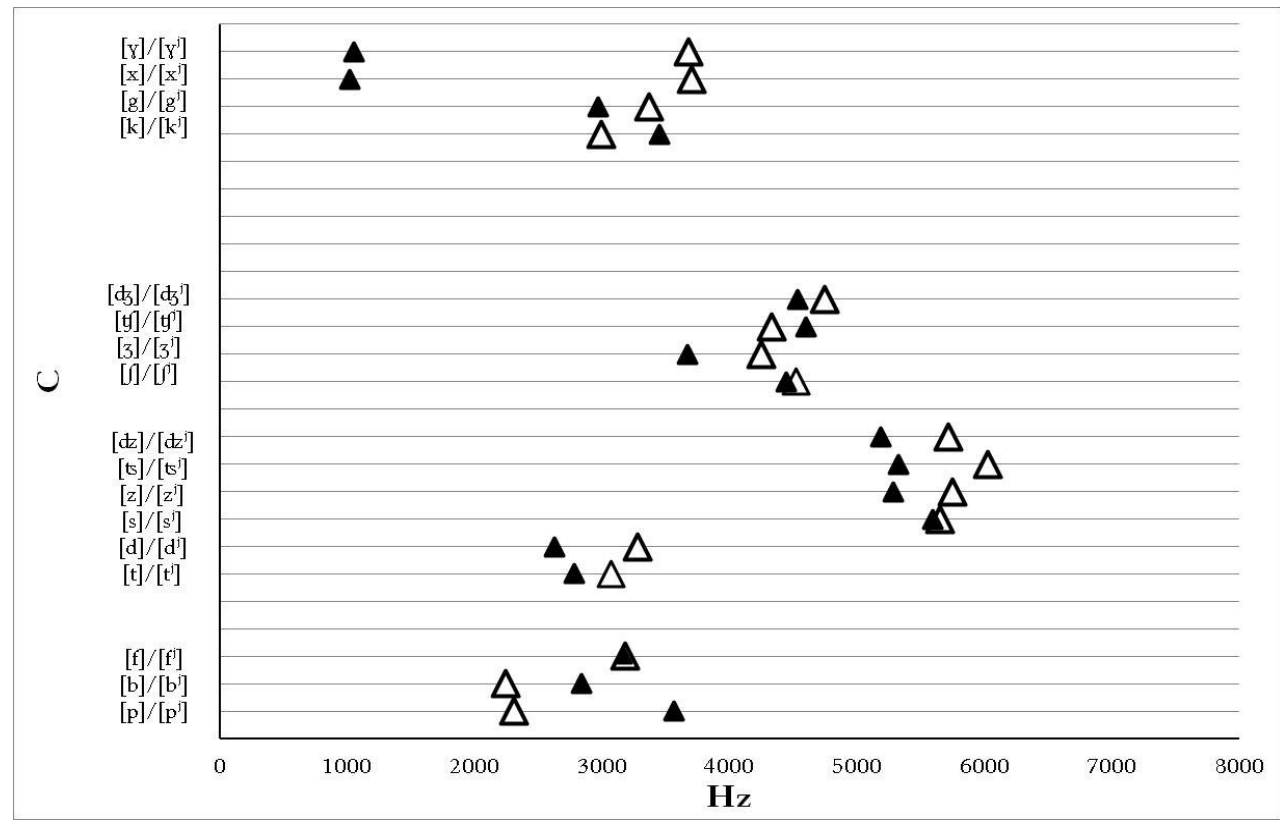

Figure 6. Frequencies of the spectral peaks: female data

( $\Delta$ non-palatalized obstruent, $\triangle$ palatalized obstruent)

The investigations show that frequencies of spectral peaks of the palatalized consonants are higher than respective non-palatalized consonants (with the exception of labial $\left[\mathrm{b}^{\mathrm{j}}\right],\left[\mathrm{p}^{\mathrm{j}}\right]<[\mathrm{p}]$, [b], palatal $\left[\mathrm{k}^{\mathrm{j}}\right],\left[\mathrm{g}^{\mathrm{j}}\right]<[\mathrm{k}],[\mathrm{g}]$ ir alveolar $\left.\left[\mathfrak{t}^{j}\right]<[\mathfrak{g}]\right)$. Secondary palatalization is an additional articulation change, which changes the height of the timbre of consonants: an additional narrowing appears in some place of the voice trail after the middle part of the tongue rises towards the hard palate due to which the oral cavity decreases and resonates in a higher timbre. The smaller the cavity of the front resonator the higher consonant formants are, and vice versa, the longer the front resonator, the lower frequencies it resonates. Spectral peaks increase due to palatalization, especially it is noticeable in the subsystem of the fricatives and affricates. Hence, the data of the spiral peak can be regarded as one (but not the only one) acoustic feature of palatalization.

2. Relative intensity shows the relation between the mean intensity of the fricative or affricate and the mean intensity of the vowel in their phonetic environment. The mean intensity shows the mean sound intensity in a given interval. The intensity of the spectral peaks of the voiceless fricatives and voiceless affricates was measured in decibels $(\mathrm{dB})$. The mean values of the intensity were obtained from the intervals with duration of 10 $\mathrm{ms}$, while the intensity of vowels was obtained from the intervals with duration of $50 \mathrm{~ms}$, located approximately in the middle of the vowel (Figures 7 and 8). The relative intensity is calculated by dividing the mean intensity value of the fricative or affricate by the mean intensity value of the 
vowel in its phonetic environment. In the group of fricatives, the intensity of the spectral peak revealed a tendency for the non-sibilants $[\mathrm{f}(:)]$ and $[\mathrm{x}(:)]$ for having the lower intensity of the spectral peak than that of the sibilants $[\mathrm{s}(:)],\left[\int(:)\right]$.

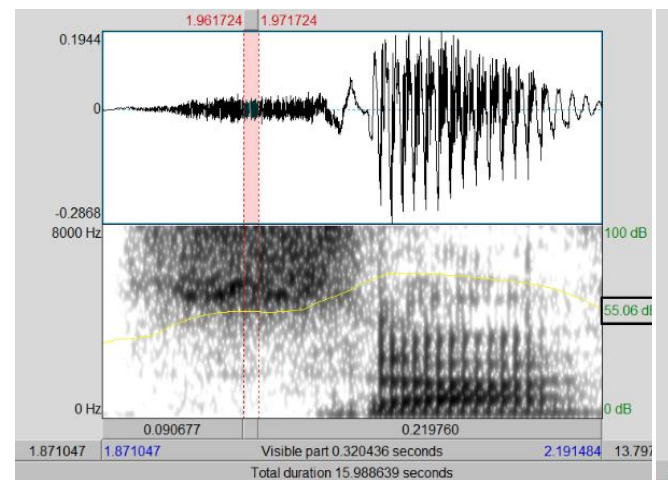

Figure 7. Voiceless prevocalic [s] in the syllable [sas]: interval of $10 \mathrm{~ms}$

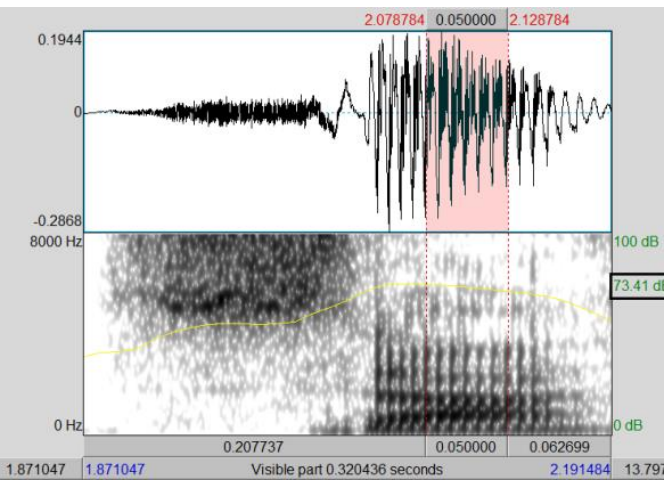

Figure 8. Vowel $[a]$ in the vocalic environment of the voiceless prevocalic fricative $[\mathrm{s}]$ in the syllable [sas]: interval of $50 \mathrm{~ms}$

Statistical means of the relative intensity for Lithuanian fricatives and obstruents increases in the following sequence (by male data):

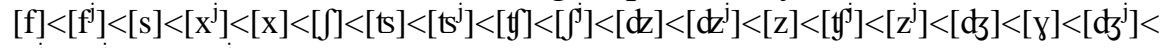
$\left[\mathrm{s}^{\mathrm{j}}\right]<\left[3^{\mathrm{j}}\right]<[3]<\left[\mathrm{\gamma}^{\mathrm{j}}\right]$.

In non-palatalized/palatalized pairs (Figure 9), palatalized consonants produced by males have a higher relative intensity (except for the palatovelar $\left[\mathrm{x}^{\mathrm{j}}\right]$ and the alveolar $\left[3^{\mathrm{j}}\right]$, which have a lower relative intensity than the nonpalatalized [x], [3]). 


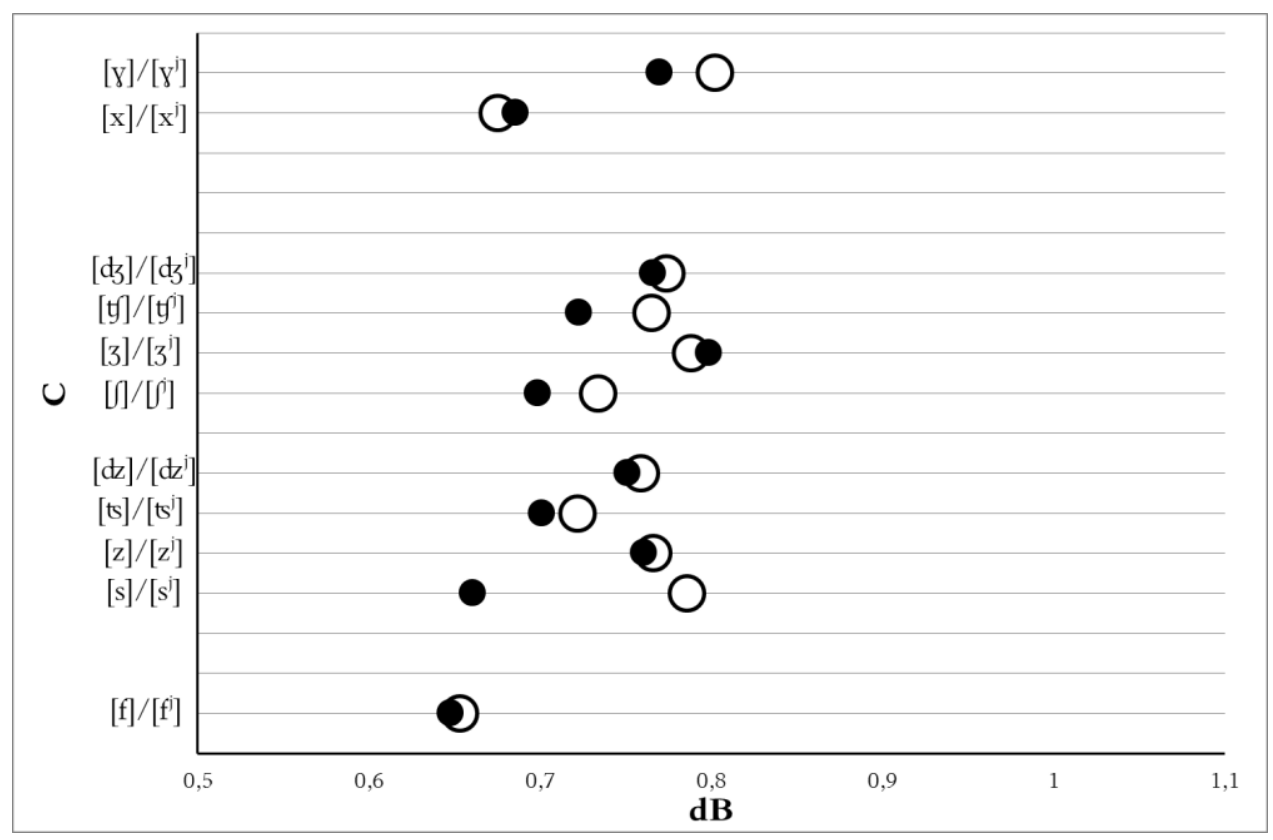

Figure 9.Relative intensity of Lithuanian plosives and affricates: male data ( non-palatalized obstruent, $\bigcirc$ palatalized obstruent)

Hence, palatalization increases a relative intensity for the sounds produced in the front part of the mouth, whereas among the sounds produced at the back of the mouth the non-palatalized variants have a higher relative intensity: $[\mathrm{f}]<\left[\mathrm{f}^{\mathrm{j}}\right],[\mathrm{s}]<\left[\mathrm{s}^{\mathrm{j}}\right],[\mathrm{f}]<\left[\mathrm{f}^{\mathrm{j}}\right],[\mathrm{ts}]<\left[\mathrm{ts}^{\mathrm{j}}\right],[\mathrm{t}]<\left[\mathrm{t}^{\mathrm{j}}\right], \quad[\mathrm{d}]<\left[\mathrm{c}^{\mathrm{j}}\right]$, $[\mathrm{z}]<\left[\mathrm{z}^{\mathrm{j}}\right]$, but: $\left[\mathrm{x}^{\mathrm{j}}\right]<[\mathrm{x}],\left[3^{\mathrm{j}}\right]<[3]$.

Results of the study show that in these palatalized/non-palatalized pairs, apart from several exceptions, the mean relative intensity for the palatalized obstruent (fricative or affricate) is usually higher than that of the corresponding non-palatalized obstruent (fricative or affricate).

3. F2 transition according to the locus equations. Since the quality of consonants (particularly the obstruents) is observed at the starting point of the vowel formants (it is the neighbouring consonant that causes the change in the vowel quality), it is likely that the starting point of the vowel formant transitions (loci) may help to interpret the patterns of coarticulation. Coarticulation causes the secondary articulation of the consonants: labialization, palatalization, velarization, etc. (see Ambrazevičius, 2011: 32, 53). In acoustic phonetics, the method of locus equations is used to study the sensitivity of consonants to coarticulatory effects. The locusequation formula ${ }^{4}$ is: $\mathbf{F} 2_{\text {onset }}=\mathbf{k} * \mathbf{F} 2_{\text {middle }}+\mathbf{c}$, where $\mathrm{F} 2_{\text {onset }}$ is $\mathrm{F} 2$ frequency at the

${ }^{4}$ Diana Krull (Krull 1988; Sussman et al. 1993) was the first researcher who used locus equations to analyse the level of consonant-to-vowel coarticulation. She applied the equation formula used by Lindblom (Lindblom, 1963). 
vowel onset, $\mathrm{F} 2$ middle is $\mathrm{F} 2$ frequency in the vowel steady-state, and $k$ and $c$ are constants. The main values used in the locus equations are the F2 frequency (in Hz) at the onset of the vowel and at its steady-state. They are measured with the given CVC sequence opened in the PRAAT window. The F2 value is displayed in PRAAT at the onset of the vowel ( $\left.\mathrm{F} 2_{\text {onset }}\right)$ after placing the mouse pointer on the transition from $\mathrm{C}$ to $\mathrm{V}$, in the centre of the first vocal vibration (Figure 10). At the point of transition the interaction between a vowel and a consonant is strongest. F2 value is obtained by placing the mouse pointer in the middle of the vowel at the steady-state $(\mathrm{F} 2$ middle), where the vowel is least exposed to the influence of the neighbouring consonants (Figure 11).

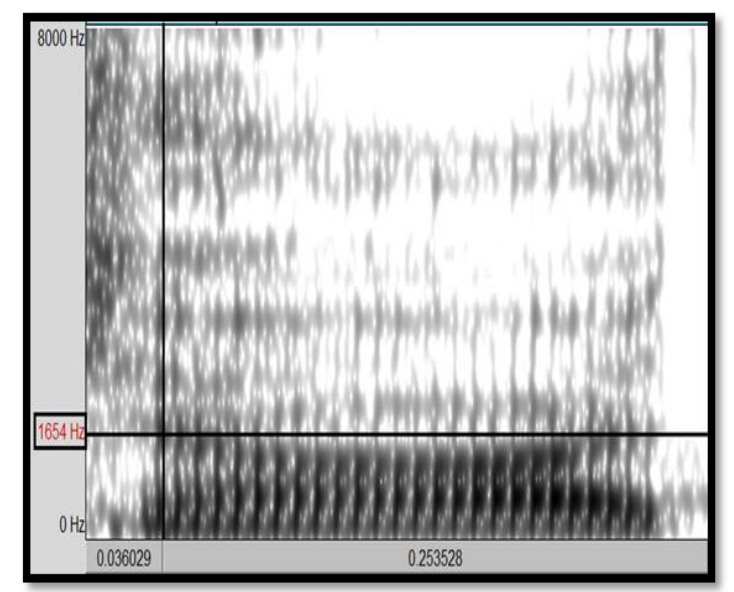

Figure 10. Obtaining the value of the onset F2 (F2 $\left.2_{\text {onset }}\right)$

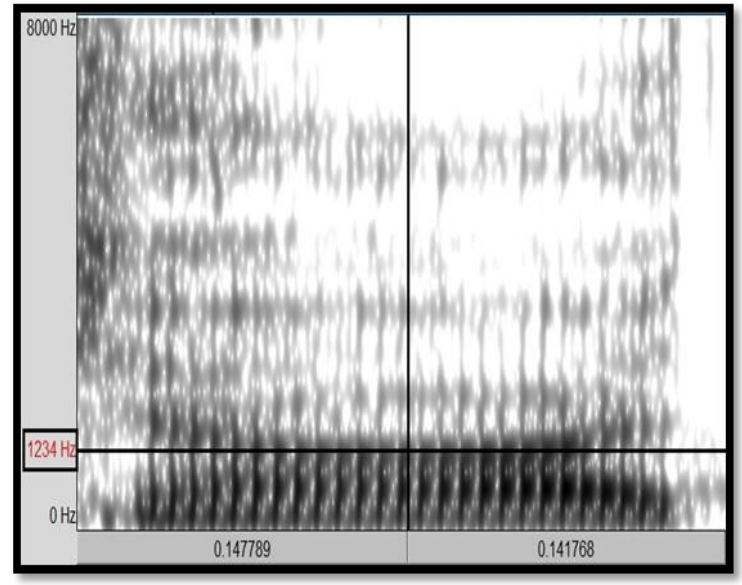

Figure 11. Obtaining the value of the middle F2 $\left(\mathrm{F} 2{ }_{\text {middle }}\right)$

Locus equations for the whole consonant inventory have been analysed. Having plotted $\mathrm{F} 2$ middle values of the $x$ axis, and the $\mathrm{F} 2$ onset values on the $y$ axis, a linear regression is obtained whose slope and y-intercept 
differ systematically according to the place of articulation of the consonant (Figure 12).

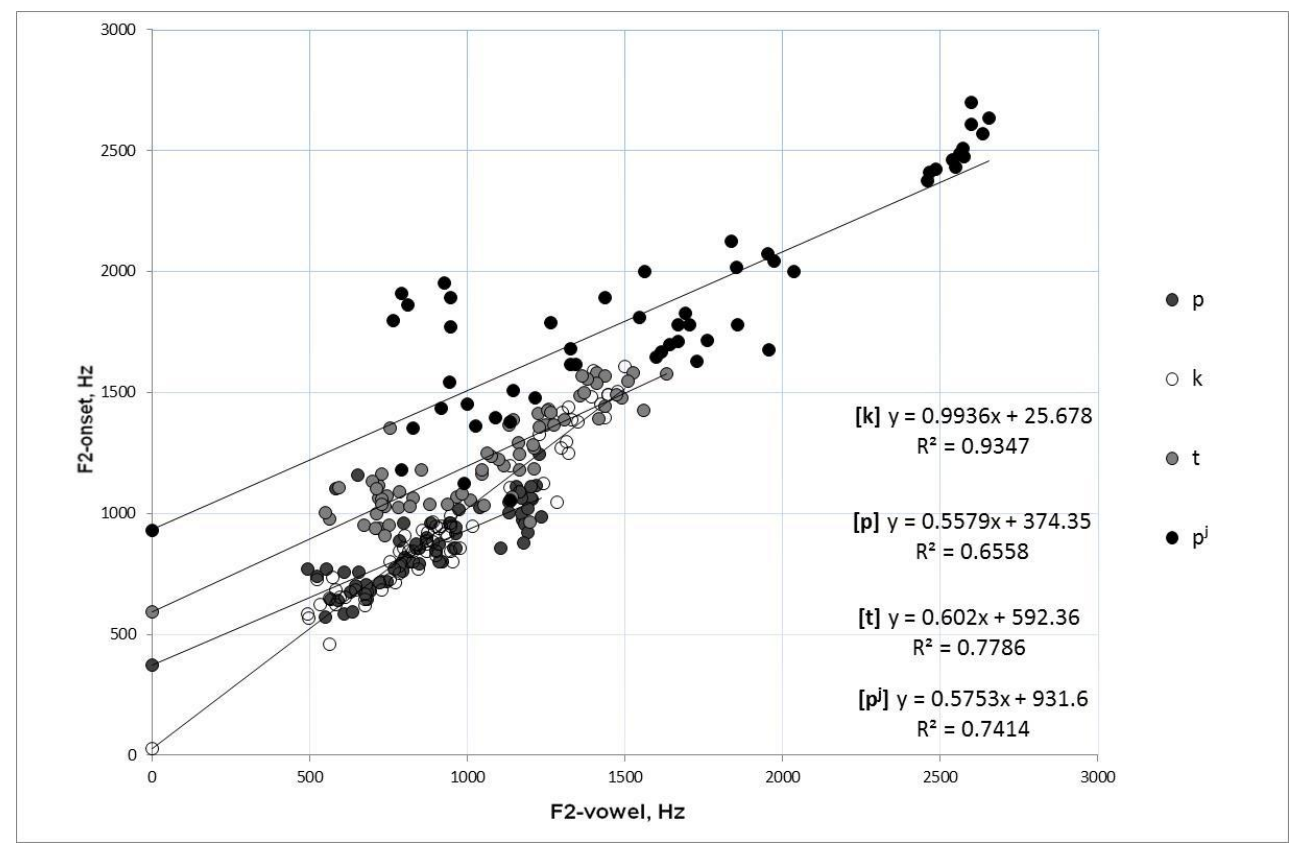

Figure 12. Comparative linear regression analysis for consonant classes

F2 loci are important to studying palatalization of consonants because when articulating the palatalized consonant F1 becomes somewhat lower, F2 sharply rises and F3 rises a little (Brosnahan, Malmberg, 1970: 67). The investigations proved that due to the palatalized consonant frequencies of the subsequent vowel become higher, which is best seen from the indices of the second formant of the vowels (Girdenis, KubiliūteKliukiene, 1982: 30 and references therein). This heightening of the second formant in case of $i$-type palatalization is related to a brief formation of the $i$-type sound in a vowel excursion. On the contrary, in case of nonpalatalized consonants allophones of the neutral vowel $a$ (šva), which lower the value of $\mathrm{F} 2$ formant, form in transition between a consonant and a vowel (Ambrazevičius, Leskauskaitè, 2014: 23; Ambrazevičius, 2012a: 13-17) ${ }^{5}$.

Having plotted the values of the slope ( $x$ - axis) and y-intercept $(y$ axis) on the plane of the coordinates (Figure 13), we see that the palatalized obstruents are arranged in the upper part of the plane, whereas non-

\footnotetext{
${ }^{5}$ Rytis Ambrazevičius and Asta Leskauskaite also relate differences in F2 loci of the hard and soft consonants to the place of constriction of the vocal tract (the so-called perturbation theory): in articulating the soft consonants an additional narrowing forms at the hard palate, which heightens F2, and in case of the hard consonants a narrowing forms at the uvula and deeper, therefore the value of F2 becomes lower (Ambrazevičius, Leskauskaitè, 2014: 26).
} 
palatalized ones are arranged in its lower part. Lower values of the slope and higher values of y-intercept are characteristic of the palatalized consonants as compared to those of their non-palatalized equivalents. The palatalized obstruents are arranged compactly, which means that the place of their articulation differed insignificantly because they all have a common feature of palatalization - the rise of the middle part of the tongue towards the hard palate. Meantime the non-palatalized consonants are spaced more widely on the plane of the coordinates because they have no articulation component uniting them.

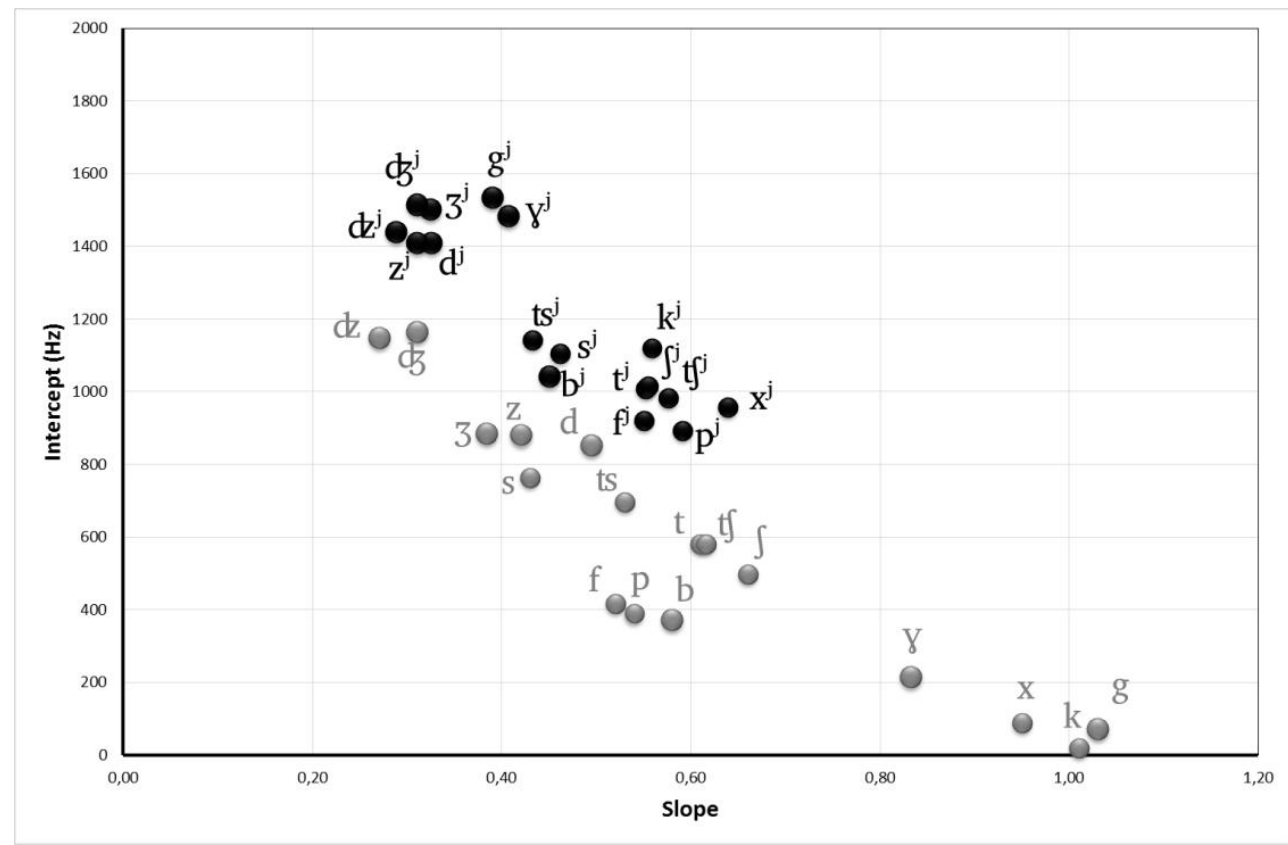

Figure 13. F2 locus: Lithuanian consonants (- non-palatalized obstruent, $\bigcirc$ palatalized obstruent)

Differences in F2 loci are not significant enough to be regarded as distinguishing features of consonant articulation; however, they can be treated as distinguishing acoustic features of palatalization of consonants.

Conclusions. There is not a single distinguishing acoustic feature of the palatalized and non-palatalized consonants that is reliable in all cases. The reliably and relatively simple cues for palatalizing vary slightly depending on the obstruents and the cases examined.According to research, palatalization of the Lithuanian obstruents is recognized by the following acoustic features:

1) frequency of the spectral peak: the frequencies of the palatalized obstruents (particularly labiodental and palatovelar fricatives and affricates) are higher; 
2) relative intensity: palatalized fricatives and affricates have a higher relative intensity;

3) indices of locus equations: palatalized consonants have lower slopes and higher y-intercepts than their non-palatalized equivalents. F2 loci of the palatalized consonants are compactly concentrated in the upper part of the plane of the coordinates, whereas loci of nonpalatalized consonants are spaced widely in its lower part. This arrangement is determined by common additional articulation (the rise of the middle part of the tongue towards the hard palate) characteristic of the palatalized consonants, and the non-palatalized consonants have no common articulation component uniting them. When identifying palatalization, loci are usually of more significance than consonant spectra.

Opposing palatalized and non-palatalized phonemes is one of four phonological oppositions characteristic of the Lithuanian consonants (LG, 2006, 44-47). Cf.:

a) palatalization opposition when the palatalized consonants contrast with the non-palatalized ones, e.g. žavùs 'charming, Nom. Sg. Masc.'- žaviùs 'charming, Acc. Pl. Masc.', gulù'(I) lie down'guliù'(I) lie', baisù 'scary' - baisiù 'awful, Instr. Sg. Masc.';

b) voicing opposition when the voiced consonants contrast with the voiceless consonants, e.g. pãdas 'sole'- bãtas 'shoe', kãras 'war'gãras 'steam', tãre 's/he, it, theysaid'-dãre 's/he, it, they did';

c) modal opposition when the consonants contrast according to the manner of articulation, e.g. sakaĩ 'you say'- takaĩ 'paths', nagaĩ 'nails'- ragaĩ 'horns', sẽmia 's/he, it, theyscoop(s)' - lẽmia 's/he, it, they fate(s)';

d) local opposition when the consonants contrast according to the place of articulation, e.g. mãras 'plague'-nãras 'diver', bùrti 'to charm'dùrti 'to puncture', šilti 'to warm'-žilti 'to turn grey'.

When looking for typological commonality and having compared Lithuanian consonantism with the system of consonants of the Latvian language, which is genetically closest to the Lithuanian language, it can be seen that the same phonological oppositions, with the exception of palatalization, i.e. the voicing opposition (būt 'to be' - pūt 'to rot', $d u \bar{s} a$ 'of the shower' - tuša 'Indian ink', grāba 'rakes' - krāpa 'cheats'), modal opposition (māja 'house' - vāja 'weak'); local opposition (bulta 'indicator' - gulta 'bed', lasi 'read' - laši 'salmons') are characteristic of the consonant phonemes of the Latvian language. Due to palatalization, the inventory of consonant phonemes of the Lithuanian language is almost twice as large (45 phonemes) as that of the Latvian language ( 26 phonemes). The system of consonants of the Latvian language is close to the basic system developed by Ian Maddieson (20 consonant phonemes). Hence, the existence of 
palatalization opposition can be treated as the most significant phonological feature distinguishing consonantism of the modern Baltic languages.

\section{References}

Ambrazevičius Rytis 2010, Differential acoustical cues for palatalized vs nonpalatalized prevocalic sonants in Lithuanian, Žmogus ir žodis 12 (1), 510.

Ambrazevičius Rytis 2011, Kalbos akustika glaustai, Kaunas: Technologija.

Ambrazevičius Rytis 2012, Akustiniai priebalsių palatalizacijos požymiai, Kalbu studijos 21, 5-13.http://dx.doi.org/10.5755/j01.sal.0.21.2073.

Ambrazevičius Rytis 2012a, Loci of palatalized vs nonpalatalized prevocalic plosivesin Lithuanian, Žmogus ir žodis 14 (1), 1318.https://etalpykla.lituanistikadb.lt/object/LT-LDB0001:J.04 2012 1367186262802/J.04 2012 1367186262802.pdf.

Ambrazevičius Rytis, Leskauskaitė Asta 2014, Priebalsiu akustinés ypatybès: palatalizacija ir balsingumas, Kaunas: Technologija.

Boersma Paul, Weenink David 2012, Praat: Doing phonetics by computer v5.3.35 [Computer software], http://www.fon.hum.uva.nl./praat/.

Brosnahan Leonard Francis, Bertil Malmberg 1970, Introduction to Phonetics, Cambridge: Cambridge University Press.

Dereškevičiūtė Sigita 2008, Dèl lietuvių kalbos sklandžiųų priebalsių kiekybės, Žmogus ir žodis 10 (1), 15-19.

Dereškevičiūtè Sigita 2013, Lietuviu kalbos priebalsiu akustinès ypatybès/ Ph.D. dissertation, Vytautas Magnus University at Kaunas. https://vb.vdu.lt/object/elaba:1994439/

Girdenis Aleksas 2000, Dèl [k], [g] minkštumo prieš kitus priebalsius, Kalbotyra 48 (1)/49 (1), 165-167.

Girdenis Aleksas 2014,Theoretical foundations of Lithuanian Phonology, Vilnius: Eugrimas.Girdenis Aleksas, Vida Karosienè 2010, Bendrinés lietuviu kalbos statistine struktūra: fonologijos dalykai, Vilnius: Vilniaus universitetas.

Girdenis Aleksas, Kubiliūtè-Kliukienè Regina 1982, Regresyvinis priebalsių palatalizacijos poveikis balsių spektrui šiaurès žemaičių tarmèje, Kalbotyra 33 (1), 30-38.

IPA 2015 -International Phonetic Alphabet 2015.https://www.internationalphoneticassociation.org/content/full-ipachart.

Johnson Keith 2003, Acoustic \& auditory phonetics,2nd ed., Oxford: Blackwell Publishers. 
Karosienè Vida, Aleksas Girdenis 1993, Bendrinès kalbos fonemų dažnumai, Kalbotyra 42 (1), 28-38.

Kazlauskienè Asta 2006, Pastabos dèl lietuvių kalbos pučiamuju priebalsių kiekybės, in Svetlana Polkovņikova (ed.), Valoda - 2006. Valoda dažādu kultūru kontekstā 16, 148-154.

Kazlauskienè Asta, Arimantas Raškinis 2006, Lietuvių kalbos sprogstamuju priebalsių kiekybè, Kalbu studijos 8, 64-69.

Kent Raymond D., Read Charles 2002, The acoustic analysis of speech, Albany: Thomson Learning.

Kliukienė Regina 2002, Regresyvinis minkštujų priebalsių poveikis trumpuju aukštutinių ir žemutinių balsių spektrui lietuvių bendrinejje kalboje, Kalbotyra 51 (1), 73-78.

Krull Diana 1988, Acoustic properties as predictors of perceptual responses: A study of Swedish voiced stops, Perilus 7, 66-70.

Lindblom Björn 1963, Spectrografic study of vowel reduction, Journal of the Acoustical Society of America 35, 1773-1781.

LG 2006: Lithuanian Grammar,edited by Vytautas Ambrazas, Vilnius: Baltos lankos.

LKG 1965 - Kazys Ulvydas (ed.), Lietuviu kalbos gramatika 1: Fonetika ir morfologija (daiktavardis, būdvardis, skaitvardis, ìvardis), Vilnius: Mintis.

Mikalauskaitė Elzbieta 1975, Lietuviu kalbos fonetikos darbai, Vilnius: Mokslas.

Pakerys Antanas 2003, Lietuviu bendrinès kalbos fonetika, Vilnius: Enciklopedija.

Sussman Harvey M., Hoemeke Kathryn A., Ahmed Farhan S 1993, A crosslinguistic investigation of locus equations as a phonetic descriptor for place of articulation, Journal of the Acoustical Society of America 94, 1256-1268.

Балшайтите Дануте 2005, Аффрикатизация смычных согласных и палатализация, Respectus philologicus 8 (13), 87-96.

Балшайтите Дануте 2006, Акустические параметры палатализации и веляризации смычных согласных современного литовского языка, Žmogusir žodis 8(1), 65-73.

Балшайтите Дануте 2007, Контраст по FIIв слогах CV/C'V типа литературного языка, Respectus philologicus 11(16), 154-162. 